\title{
Effects of Organic and Microbial Fertilizers on Striga hermonthica in Maize
}

\author{
Osman A. G. ${ }^{1}$, Hassan M. M. ${ }^{1,{ }^{*},}$, Rugheim A. M. E. ${ }^{2}$, Abdelgani M. E. ${ }^{1}$, Babiker A. E. $^{3}$ \\ ${ }^{1}$ Environment and Natural Resources Research Institute, National Centre for Research, Khartoum, Sudan \\ ${ }^{2}$ Faculty of Agriculture, Omdurman Islamic University, Omdurman Sudan \\ ${ }^{3}$ College of Agricultural Studies, Sudan University of Science and Technology, Khartoum, Sudan \\ *Corresponding Author: mohkadis@yahoo.com
}

Copyright (C) 2013 Horizon Research Publishing All rights reserved.

\begin{abstract}
A pot experiment was conducted at the Environment and Natural Resources Research Institute, NCR, Sudan to investigate the effect of organic (Elkhairat (T) and Elkhasseb (X)) and microbial (Azospirillin (A) and Phosphobacterin (B)) bio-fertilizers and their combinations on $S$. hermonthica growth and development in Maize. Results showed that all treatments reduced emergence of the parasite, except inoculation with A which enhanced Striga emergence compared to control. Treating maize plants with Striga, irrespective to treatments reduced maize height as compared with free maize. Plants fertilized with T sustained the highest plant growth at 4 weeks after sowing (WAS). It increased maize height by $79 \%$ as compared to infested control. At 6 WAS fertilization with $\mathrm{X}, \mathrm{B}+\mathrm{T}$ and $\mathrm{A}+\mathrm{B}+\mathrm{T}$ were significantly increased plant heights as compared to infested control. Leaf number was affected due to Striga infestation. At 6 WAS, all treatments significantly increased leaf numbers except $\mathrm{B}, \mathrm{A}+\mathrm{B}$ and $\mathrm{X}$ as compared to infested control. While at $10 \mathrm{WAS}$, results showed that only $\mathrm{A}+\mathrm{B}+\mathrm{T}$ was significantly increased leaf numbers compared to infested control. Averaged across all fertilization treatments, maize plants infested with Striga had smaller leaf areas than did uninfected plants. At 6 and 10 WAS, X sustained the highest leaf area index compared to all other treatments. Maize treated with $\mathrm{X}$ and $\mathrm{A}+\mathrm{B}+\mathrm{T}$ sustained the highest shoot dry weight as compared to infested control . Maize fertilized with $\mathrm{X}, \mathrm{A}+\mathrm{T}$ and $\mathrm{A}+\mathrm{X}$ showed the highest root dry weight as compared to infested control.
\end{abstract}

Keywords Striga Hermonthica, Maize, Organic And Microbial Fertilizers

\section{Introduction}

Maize (Zea mays L.) is widely cultivated throughout the world and greater weight of maize is produced each year than any grain, the United States produced $40 \%$ of the world's harvest. Other top producing countries are China, Brazil,
Mexico, Indonesia, India, France and Argentina. World wide production was 817 million tones in 2009 - more than rice (678 million tones) or wheat (682 million tones) (1). Maize yield is very low, due to constraints of nutrient depletion, loss of organic matter and poor and erratic rainfall. Maize production also is negatively influenced by the incidence of pests and diseases and increasingly by the parasitic weed Striga.

The genus Striga (Orobanchaceae, formerly Scrophulariaceae) is one of the most important biotic constraints affecting crop production. Yield losses in staple cereal crops damage by Striga varied from a few percentages up to complete crop failure depending on factors such as crop species, level of infestation rainfall pattern and soil degradation (2). S. hermonthica (Del.) Benth and S. asiatica (L.) kuntze are the two most wide spread and the most economically significant species that parasitize on sorghum (Sorghum bicolor), Pearl millet (Pennisetum glaucum (L.) R. Br.) Maize (Zea mays (L.)) and rice (Oryza sativa (L.)), whereas S. gesnerioides (Willd.) Vatke attacks crops such as cowpea (Vigna unguiculata L. Walp) and peanut (Arachis hypogaea L.) $(3,4)$. Striga is most severe in low moisture and low soil fertility.

Manure spreading in the planting furrows has been a known practice by local farmers in order to improve the growth of crop plants and to reduce broomrape infestation (5).

Intensive research is underway in order to achieve better management of witchweed and broomrape, especially with environment-friendly approaches. Many workshops on parasitic weeds in general or specifically on Striga discussed various management methods, and claim various levels of success (6). The search for satisfactory control methods of this parasite is a continuous task. The objective of this research was to study the effects of organic and microbial bio-fertilizers on Striga infested maize plants under green house condition.

\section{Materials and Methods}


The materials used in this experiment included different organic (Elkhairat and Elkhasseb) and microbial fertilizers (Azospirillum brazilense (Azospirillin); and Bacillus Megatherium var. phosphaticum). Maize (Zea maize L.) was used as the test plant for Striga infestation. Striga hermonthica seeds were collected in 2006 from infested sorghum plants at the Gezira Research Station, Sudan.

\section{Elkhairat Compost}

It is compost produced commercially in Sudan. It is a mixture of plant residues and animal manure. It was obtained from Elkhairat Company, Khartoum, Sudan. It started in 2007 producing small quantities $(1 \mathrm{t} / \mathrm{month})$ applied to nurseries and house gardens. In 2008 the factory was established in an area of 5.5 feddans at Elselate Scheme and the average production was $5 \mathrm{t} / \mathrm{month}$, The average production rate in 2009 reached $150 \mathrm{t} / \mathrm{month}$. It is packaged in two cans $50 \mathrm{Kg}$ or $2 \mathrm{Kg}$ sacs and available in the market (7).

\section{Elkhasseb Organic Fertilizer}

Elkhasseb organic fertilizer is manufactured locally in El Bagair industrial area, Khartoum, Sudan. It is a mixture of sheep manure, farmyard manure and chicken in 1:2:1 ratio. It is heated up to $70^{\circ} \mathrm{C}$ for 30 minutes and then belted $(2.5,4$ millimeter), it is free from plastic materials, weeds seeds, insects, warms, nematode and pathogenic microorganisms (Shigella, Salmonella and E. coli). The analysis of this fertilizer proved that, heavy metals, micronutrients, sodium, potassium chlorine, total nitrogen, C.N ratio, $\mathrm{EC}, \mathrm{pH}$, bulk density, strange materials were within the range compared to finished compost. However, calcium carbonate, phosphorus lignin, cellulose, hemi cellulose and fiber were all over the standard range compared to finished compost. CEC and magnesium were lower than the standard range (Annual Scientific Report of the Environment and Natural Resources Research Institute, 2). It was obtained from Elkhasseb Company.

Table 1. Chemical composition of organic fertilizers

\begin{tabular}{|c|c|c|c|c|c|c|c|}
\hline Fertilizers & O.C \% & $\begin{array}{c}\mathbf{N} \\
\mathbf{\%}\end{array}$ & K mmol & Na mmol & Mg \% & $\begin{array}{c}\text { Ca } \\
\mathbf{\%}\end{array}$ & $\begin{array}{c}\text { P } \\
\mathbf{\%}\end{array}$ \\
\hline Elkhaseeb & 32.5 & 1.41 & 6.99 & 4.44 & 3.0 & 5.0 & 0.7 \\
\hline Elkhairat & 11.7 & 1.02 & 4.35 & 1.98 & 4.5 & 5.8 & 0.3 \\
\hline
\end{tabular}

Table 2. Average numbers of emerging Striga plants

\begin{tabular}{|c|c|c|c|c|c|c|c|c|}
\hline \multirow{2}{*}{ Treatment } & \multicolumn{8}{|c|}{ Weeks After Sowing (WAS) } \\
\hline & 6 & 7 & 8 & 9 & 10 & 11 & 12 & 13 \\
\hline Control 1 & 0 & 0 & 0 & 0 & 0 & 0 & 0 & 0 \\
\hline Control 2 & 2.50 & 1.00 & 2.25 & 2.25 & 3.25 & 3.25 & 3.25 & 4.75 \\
\hline $\mathbf{A}$ & 3.00 & 2.25 & 3.25 & 3.25 & 3.50 & 3.25 & 3.25 & 6.75 \\
\hline $\mathbf{B}$ & 1.75 & 2.75 & 3.25 & 4.00 & 4.00 & 4.00 & 4.00 & 11.75 \\
\hline $\mathbf{A}+\mathbf{B}$ & 1.25 & 1.75 & 3.00 & 3.00 & 1.75 & 2.00 & 2.00 & 12.00 \\
\hline $\mathbf{T}$ & 0.00 & 2.50 & 2.00 & 2.75 & 3.25 & 3.25 & 3.25 & 11.75 \\
\hline $\mathbf{X}$ & 2.50 & 2.50 & 1.00 & 4.25 & 1.00 & 1.00 & 1.00 & 1.00 \\
\hline $\mathbf{A}+\mathbf{T}$ & 1.25 & 2.25 & 1.75 & 4.25 & 4.25 & 4.00 & 4.00 & 7.50 \\
\hline$A+X$ & 0.00 & 3.00 & 3.25 & 2.00 & 1.75 & 1.75 & 1.75 & 10.75 \\
\hline $\mathbf{B}+\mathbf{T}$ & 1.00 & 1.50 & 2.75 & 2.25 & 4.00 & 4.00 & 1.75 & 7.00 \\
\hline $\mathbf{B}+\mathbf{X}$ & 0.00 & 2.75 & 1.00 & 1.00 & 1.25 & 1.75 & 1.75 & 8.75 \\
\hline $\mathbf{A}+\mathbf{B}+\mathbf{T}$ & 2.50 & 1.00 & 2.50 & 1.25 & 1.25 & 1.25 & 1.25 & 2.00 \\
\hline $\mathbf{A}+\mathbf{B}+\mathbf{X}$ & 1.25 & 2.00 & 1.00 & 2.50 & 3.00 & 3.00 & 3.00 & 9.50 \\
\hline LSD & 2.51 & 2.80 & 2.20 & 2.32 & 2.78 & 2.78 & 6.60 & 2.68 \\
\hline
\end{tabular}

Control $1=$ un-infested Control $2=$ infested 


\section{Microbial Bio-fertilizers}

A broth medium of meat peptone was prepared by adding the following constituents $(\mathrm{g})$ to a liter of distilled water: 7.5 peptone, 5 meat extract and $5 \mathrm{NaCl}$. The medium was sterilized by autoclaving at $121^{\circ} \mathrm{C}$ and $15 \mathrm{ib} / \mathrm{in}^{2}$ for 15 minutes. The broth was then inoculated by Azospirillum brazilense (Azospirillin) and Bacillus Megatherium var. phosphaticum (Phosphorin) separately. The inoculated broth was aerated by shaking for $24 \mathrm{hrs}$. A sample was taken from the broth for the determination of the number of cells $/ \mathrm{ml}$ using the pour plate method to ensure maturity of inoculant $\left(1 \times 10^{9} \mathrm{cell} / \mathrm{ml}\right)$.

\section{Maize Greenhouse Experiment}

This study was conducted at the Environment and Natural Resources Research Institute, the National Center for Research, Khartoum- Sudan. In this experiment, soil mix made of Nile silt and sand $(2: 1 \mathrm{v} / \mathrm{v})$ was used in plastic pots each containing $5 \mathrm{~kg}$ soil. Pots were either fertilized with Elkhairat or Elkhasseb organic fertilizer before sowing at a rate of $20 \mathrm{~g} /$ pot. Striga infestation was accomplished by mixing $10 \mathrm{mg}$ of seeds in the top soil in each pot. Maize seeds were either inoculated with Azospirillin or Phosphobacterin each alone or in combinations with organic fertilizers. Striga infested and un-infested maize controls were included in each experiment for comparison. Maize seeds (7/pot) were sown and pots were then irrigated by equal amount of tab water every two days. Aliquots of the respective bacterial suspensions (15 $\mathrm{ml}$ each) were injected, within the root zone, in each pot. Subsequent irrigations were repeated every 2 days. Germinated maize was thinned to three plants per pot at 10 days after planting.

Striga infestation was assessed by the number of emerged shoots weekly beginning from the first Striga emergence. Maize plant height was recorded at five and nine weeks after sowing (WAS). Leaf area index (LAI) was measured at 6 and 10 WAS. LAI per plant was calculated by dividing the leaf area per plant by the total land area occupied by the plant according to the formula:

LAI=Leaf area per plant $(\mathrm{cm} 2)$

Land area occupied by the plant $(\mathrm{cm} 2)$

Maize shoot and root dry weights were recorded at the end of the experiment. The experiment was arranged in a Randomized Complete Block Design (RCBD) with four replications. Means of four replications were analyzed for variance and significant differences were determined by LSD test at the $5 \%$ probability level.

\section{Results and Discussion}

\section{Striga Incidence}

At 6 weeks after sowing (WAS), Striga was observed in all treatments except A $+\mathrm{X}$ treatment. Striga emergence was very low as only 2 on un-inoculated control (Table 2). All treatments reduced emergence of the parasite, except inoculation with Azospirillin which increased the numbers of Striga emergence as compared to control. Sorghum treated with the $\mathrm{T}, \mathrm{A}+\mathrm{X}$ and $\mathrm{B}+\mathrm{X}$ displayed no Striga emergence. At 7 WAS, Striga emergence increased, substantially. Maize treated with the combinations between A+B showed adverse effects on Striga emergence. A+B+T was the most suppressive treatment. It reduced Striga infestation by $56 \%$. However, maize fertilized with the combinations between $\mathrm{A}+\mathrm{X}$ sustained the highest parasite emergence as compared with the control albeit not significantly. At 8 WAS, Fertilization of maize with X, B+X and $\mathrm{A}+\mathrm{B}+\mathrm{X}$ reduced Striga infestation by $60 \%$ as compared to the control. While maize treated with the A, B or combinations between $\mathrm{A}+\mathrm{X}$ they increased Striga emergence by $30 \%$. At 9 WAS, maize fertilization with the combinations between $\mathrm{B}, \mathrm{X}$ or $\mathrm{A}+\mathrm{T}$ increased Striga infestation by $45-52 \%$, while maize treated with the combinations between $\mathrm{B}+\mathrm{X}$ and $\mathrm{A}+\mathrm{B}+\mathrm{T}$ it reduced Striga emergence by $55-64 \%$. At 10 WAS, Striga emergence increased, substantially and was highest on the un-inoculated control (4.25 Striga/bag). In among all treatments Striga emergence began to increased except in the combinations between $\mathrm{A}+\mathrm{B}, \mathrm{A}+\mathrm{X}, \mathrm{B}+\mathrm{X}, \mathrm{A}+\mathrm{B}+\mathrm{T}$ or $\mathrm{X}$ alone. At 11,12 and 13 WAS, Striga incidence followed the same trend as at eight WAS. The counts begin to decline in Striga incidence with obvious trends. In among all treatments combinations of $\mathrm{A}+\mathrm{B}+\mathrm{T}$ were the inhibitoriest. Manure-free soil had the highest broomrape infestation.

Table 3. Effects of different treatments on plant height $(\mathrm{cm})$

\begin{tabular}{|c|c|c|c|}
\hline Treatment & $\mathbf{4}$ WAS & $\begin{array}{c}\mathbf{6} \\
\text { WAS }\end{array}$ & $\begin{array}{c}\mathbf{8} \\
\text { WAS }\end{array}$ \\
\hline Control (un-infested) & 22.5 & 27.8 & 28.4 \\
Control (infested) & 10.4 & 20.7 & 21.3 \\
Azospirillin(A) & 27.9 & 25.2 & 25.5 \\
Phosphorin(B) & 19.2 & 24.5 & 24.9 \\
A+B & 9.7 & 12.6 & 13.1 \\
ElKhairat (T) & 72.5 & 27.7 & 28.4 \\
ElKhaseeb (X) & 15.2 & 32.5 & 32.7 \\
A+T & 23.2 & 27.7 & 28.1 \\
A+X & 21.9 & 28.1 & 28.7 \\
B+T & 22.2 & 29.3 & 29.8 \\
B+X & 11.7 & 24.5 & 24.7 \\
A+B+T & 19.5 & 30.3 & 30.5 \\
A+B+X & 18.1 & 24.4 & 24.9 \\
\hline LSD & $\mathbf{5 . 0}$ & $\mathbf{7 . 4}$ & $\mathbf{8 . 0}$ \\
\hline
\end{tabular}

\section{Leaf Numbers}

Leaf number was affected due to striga infestation. At 6 WAS, all treatments significantly increased leaf numbers 
except $\mathrm{B}, \mathrm{A}+\mathrm{B}$ and $\mathrm{X}$ as compared to infested control (table 4). While at $10 \mathrm{WAS}$, results showed that only $\mathrm{A}+\mathrm{B}+\mathrm{T}$ was significantly increased leaf numbers compared to infested control. In contrast to our findings, Gebremedhin et al., (12) found that leaf number was unaffected due to Striga infestation.

Table 4. Effects of different treatments on leaf numbers

\begin{tabular}{|c|c|c|}
\hline Treatment & $\begin{array}{c}6 \\
\text { WAS } \\
\end{array}$ & $\begin{array}{c}10 \\
\text { WAS }\end{array}$ \\
\hline Control (un-infested) & 25.3 & 21.3 \\
\hline Control (infested) & 18.8 & 18.3 \\
\hline Azospirillin(A) & 21.5 & 18.8 \\
\hline Phosphorin(B) & 20.0 & 16.0 \\
\hline $\mathbf{A}+\mathbf{B}$ & 20.3 & 19.0 \\
\hline ElKhairat (T) & 23.3 & 16.0 \\
\hline ElKhaseeb (X) & 18.8 & 15.8 \\
\hline $\mathbf{A}+\mathbf{T}$ & 22.3 & 18.5 \\
\hline $\mathbf{A}+\mathbf{X}$ & 21.8 & 18.3 \\
\hline $\mathbf{B}+\mathbf{T}$ & 21.3 & 17.3 \\
\hline $\mathbf{B}+\mathbf{X}$ & 22.5 & 19.5 \\
\hline $\mathbf{A}+\mathbf{B}+\mathbf{T}$ & 22.8 & 20.0 \\
\hline $\mathbf{A}+\mathbf{B}+\mathbf{X}$ & 24.3 & 18.5 \\
\hline LSD & 1.7 & 1.6 \\
\hline
\end{tabular}

Table 5. Effects of different treatments on leaf area index

\begin{tabular}{|c|c|c|}
\hline Treatment & $\begin{array}{c}6 \\
\text { WAS }\end{array}$ & $\begin{array}{c}10 \\
\text { WAS }\end{array}$ \\
\hline Control (un-infested) & 20.58 & 27.14 \\
\hline Control (infested) & 12.50 & 14.12 \\
\hline Azospirillin(A) & 26.80 & 30.59 \\
\hline Phosphorin(B) & 21.19 & 25.54 \\
\hline $\mathbf{A}+\mathbf{B}$ & 5.00 & 8.12 \\
\hline ElKhairat (T) & 26.42 & 28.92 \\
\hline ElKhaseeb (X) & 35.15 & 37.90 \\
\hline $\mathbf{A}+\mathbf{T}$ & 29.61 & 32.65 \\
\hline $\mathbf{A}+\mathbf{X}$ & 27.56 & 28.75 \\
\hline $\mathbf{B}+\mathbf{T}$ & 25.86 & 28.53 \\
\hline $\mathbf{B}+\mathbf{X}$ & 17.43 & 20.76 \\
\hline $\mathbf{A}+\mathbf{B}+\mathbf{T}$ & 27.21 & 28.53 \\
\hline $\mathbf{A}+\mathbf{B}+\mathbf{X}$ & 31.77 & 21.06 \\
\hline LSD & 11.60 & 12.480 \\
\hline
\end{tabular}

\section{Leaf Area Index}

Averaged across all fertilization treatments, maize plants infected with Striga had smaller leaf areas than did uninfected plants. The leaf area of infected and uninfected plants increased asymptotically from emergence to 10 WAS. At both sampling times $\mathrm{X}$ sustained the highest leaf area index compared to all other treatments (Table5).

Infection with $S$. hermonthica reduced the leaf area of the maize host from emergence to harvest. This result confirms those reported for the sorghum- $S$. hermonthica association obtained by Press and Stewart (13), Cechin and Press (14), Frost et al. (15), and for the millet-S. hermonthica association obtained by Graves et al (16). In this study, leaf area for both infected and uninfected maize plants increased asymptotically from the first to the last sampling date but the differences in leaf area between infected and uninfected maize increased with time, demonstrating the progressively deleterious effect of Striga on its host.

\section{Dry Matter}

At 13 WAS maize free shoot dry weight displayed the highest weight as compared with maize infested, irrespective to treatments. Maize treated with $\mathrm{A}+\mathrm{B}, \mathrm{A}+\mathrm{X}, \mathrm{A}+\mathrm{T}$ and $\mathrm{X}$ sustained the highest shoot dry weight albeit not significantly as compared to infested control (Table 6).

With respect to root dry weight, results displayed that maize inoculated with $\mathrm{A}+\mathrm{B}+\mathrm{T}, \mathrm{X}$, and $\mathrm{B}+\mathrm{T}$ showed the highest dry weight as compared to infested control (Table 6).

Table 6. Effects of different treatments on shoot dry weight (13 WAS)

\begin{tabular}{|c|c|c|}
\hline Treatment & $\begin{array}{c}\text { Root dry } \\
\text { weight (g) }\end{array}$ & $\begin{array}{l}\text { Shoot dry } \\
\text { weight (g) }\end{array}$ \\
\hline Control (un-infested) & 2.38 & 3.42 \\
\hline Control (infested) & 3.81 & 3.08 \\
\hline Azospirillin(A) & 3.14 & 3.14 \\
\hline Phosphorin(B) & 1.87 & 3.58 \\
\hline $\mathbf{A}+\mathbf{B}$ & 5.42 & 2.35 \\
\hline ElKhairat (T) & 3.12 & 2.89 \\
\hline ElKhaseeb (X) & 5.16 & 4.98 \\
\hline $\mathbf{A}+\mathbf{T}$ & 5.17 & 3.41 \\
\hline $\mathbf{A}+\mathbf{X}$ & 5.34 & 3.75 \\
\hline $\mathbf{B}+\mathbf{T}$ & 2.48 & 4.04 \\
\hline $\mathbf{B}+\mathbf{X}$ & 4.06 & 3.35 \\
\hline $\mathbf{A}+\mathbf{B}+\mathbf{T}$ & 4.54 & 5.02 \\
\hline $\mathbf{A}+\mathbf{B}+\mathbf{X}$ & 2.20 & 3.54 \\
\hline LSD & 5.00 & 2.41 \\
\hline
\end{tabular}

Infection of maize by $S$. hermonthica did not affect root biomass but led to smaller shoot biomass; the differences in shoot biomass between uninfected and infected plants increased with time. However, the proportion of total biomass per plant partitioned to roots differed between 
infected and uninfected plants in both experiments. The results from this study contrast with those of Graves et al. (16) and Taylor et al. (18) but are similar to those of Graves et al. (17) Cechin and Press (14). Graves et al. (16) reported that leaf and root biomasses in Striga-infected millet were increased by 41 and $86 \%$ respectively while grain yield was reduced by $80 \%$ and stem dry weight by $53 \%$. Similarly, Taylor et al. (18) found higher root biomass in infected maize than in uninfected maize, Press et al. (16) reported a marked shift in allocation of dry matter to roots in two sorghum cultivars, CSH-1 and Ochuti, infected with $S$. hermonthica. Frost et al. (15) showed that although the biomass of Striga-infected sorghum (CSH-1 and Ochuti) was lower than that in uninfected plants, shoot biomass was affected more than was root biomass. In sorghum, Graves et al. (17) reported a reduction in grain and stem dry weights while leaf and root dry weights remained similar for infected and uninfected plants. The physiological basis for these differences in response is unknown. It is possible that variations in genetic composition of different host crops and cultivars of the same species to different strains of the parasite may play a part. Changes in the balance of plant growth hormones may be responsible for some of the differences in lometry $(20,15,18)$. Another possible reason for the observed differences in lometry may be the time of emergence of parasites above ground. The data from this study showed that differences in leaf area and shoot biomass between infected and uninfected plants increased with time and the development of the Striga shoots. These results, however, did not support the hypothesis that higher applications of $\mathrm{N}$ would reduce biomass of infected maize relatively more than un- infected maize.

Reference (21) reported that if managed properly, manure composting in planting furrows contributes to the reduction of environmental pollution. Composting manure would offer a new environmentally safe procedure to manage broomrape using farm resources at the minimum cost.

\section{REFERENCES}

[1] F.A.O, (2009).Food and Agriculture Organization of the United Nations, Statistics Division "Maize, rice and wheat : area harvested, production quantity, yield". http://faostat.fao.org/site/567/DesktopDefault.aspx?PageI $\mathrm{D}=567$.

[2] Weber, G.; Elemo, K., Lagoke, S.T.O.; Awad, S. and Oikeh, A. 1995. Population dynamics and determinants of Striga hermonthica on maize and sorghum in savanna farming systems. Crop protection 14: 283-290.

[3] Parker, C. 1991. Protection of crops against parasitic weeds. Crop protection 10: 6-22.

[4] Oswald , A . 2005. Striga control technology and their dissemination. Crop Protection 24: 333 - 342.

[5] Gharib, M. S. 1973. Biological and Economic Aspects
ofBroomrapes, Orobanche pp. In northern Iraq. In: Kasasian L, C. Parker, A.R. Saghir, and V. Der Zweep (eds.). Symposium on Parasitic Weeds. Proceedings European Weed Research Council. 11-13 Apr. 1973. Pages:44-47.

[6] Mohamed, K. I., Musselman, L. J., Aigbokhan E. I., and Berner, D. K. 1996. Evolution and taxonomy of agronomically important Striga species. In: Moreno, M. T. and Cubero, J. I. eds. Advances in Parasitic Plant Research, 6th International Parasitic weed Symposium, Cordoba, Spain, pp. 54-73.

[7] Elhassan, G. A., Abdelgani, M. E., Osman, A. G., Mohamed, S. S. and Abdelgadir, B. S. (2010). Potential production and application of biofertilizers in Sudan. Pakistan Journal of Nutrition, 9 (9): 926-934.

[8] Simpson K 1986. Fertilizers and Manures. Longman, London. Chapter 8, pp.: 83-108. Annual Scientific Report of the Environment and Natural Resources Research Institute, 2009. The National Centre for Research, Khartoum-Sudan.

[9] Conn ,K.L.; Lazarovits ,G.;1999 . Impact of animal manureson on vertical Lum Wilt, potato seed, and soil microbial populations. Can.J .plant pathol. 21,81 - 92 .

[10] Vanhezewijk, M.J., Verkleij, J.A.C., 1996. The effect of nitrogenous compounds on in vitro germination of Orobanche crenata Forsk. Weed Ras 36,395-404.

[11] Lagoke, S. T. O.; Parkinson, V. and Agunbiade, R. M. 1991. Parasitic weeds and control methods in Africa. In: Combating Striga in Africa (Kim, S.K. ed.) pp. 3-14. Workshop organized by IITA, ICRISAT, and IDRC, Ibadan Nigeria.

[12] Gebremedhin, W.; Goudriaan, J. and Naber, H. 2000. Morphological, phenological and water-use dynamics of sorghum varieties (Sorghum bicolor) under Striga hermonthica infestation. Crop Protection 19: 61-68.

[13] Press, M. C. and Stewart, G. R. 1987. Growth and photosynthesis in Sorghum bicolor infected with Striga hermonthica. Annals of Botany 60: 657-662.

[14] Cechin, I. and Press, M. C. 1993. Nitrogen relations of the sorghum-Striga hermonthica host parasite association: growth and photosynthesis. Plant Cell and Environment 16: 237-247.

[15] Frost, D. L., Gurney, A. L., Press, M. C. and Scholes, J. D. 1997. Striga hermonthica reduces photosynthesis in sorghum: The importance of stomatal limitations and a potential role for ABA. Plant, Cell and Environment 20: 483-492.

[16] Graves, J. D.; Wylde, A.; Press, M. C. and Stewart, G. R. 1990. Growth and carbon allocation in Pennisetum typhoides infected with the parasitic angiosperm Striga hermonthica. Plant Cell and Environment 13: 367-373.

[17] Graves, J. D.; Press, M. C. and Stewart, G. R. 1989. A carbon balance model of the sorghum Striga hermonthica host-parasite association. Plant Cell and Environment 12: 101-108.

[18] Taylor, A., Martin, J. and Seel, W. E. 1996. Physiology of the parasitic association between maize and witch weed (Striga hermonthica). Journal of Experimental Botany 47:1057-1065.

[19] Press, M.C. Gurney, A. L. Frost, D. L. and Scholes, J. D. 1996. 
How does the parasitic angiosperm Striga hermonthica influence host growth and carbon relations? In Advances in Parasitic Plant Research, 303-310 (Eds M. T. Moreno, J. I. Cubero, D. Berner, D. Joel and L. J. Musselman). Spain: Direccion General de Investigacion Agraria, Cordoba.

[20] Drennan, D. S. H. and El Hiweris, S. O. 1979. Changes in growth regulating substances in Sorghum vulgare infected by Striga hermonthica. In: Proceedings of the second Symposium of Parasitic Weeds. (Musselman, L.J. Worsham,
A.D. and Eplee, R.E. eds.) pp 144-155. North Carolina State University. Raleigh, USA.

[21] Abu-Irmaileh, BE, Abu-Rayyan AM 2006. Pre-Plant Black Plastic Mulching and Manure Composting for Controlling Hemp Broomrape (Orobanche ramosa) in Tomato. Jordan Journal of Agricultural Sciences, 2:54-63. 